\title{
Formation of metal oxide-based hydroxysodalite by alkali-activation of kaolinite
}

\author{
Ehab AlShamaileh ${ }^{{ }^{*}}$, \\ Muayad Esaifan', \\ Qusay Abu-Afifeh ${ }^{1}$ \\ ${ }^{1}$ Department of Chemistry, \\ School of Science, \\ The University of Jordan, \\ Amman 11942, Jordan \\ ${ }^{2}$ Department of Chemistry, \\ Faculty of Science and Arts, \\ University of Petra, \\ Amman, Jordan
}

\begin{abstract}
The formation of metal oxide-based hydroxysodalite by alkali-activation of kaolinite is studied using X-ray diffraction (XRD) study and differential scanning calorimetry (DSC) analysis. Different metal oxides (CoO, $\mathrm{MgO}, \mathrm{FeO}$ and $\mathrm{SiO}_{2}$ ) were used to form the metal oxide-based hydroxysodalite. The transformation from kaolinite into hydroxysodalite is confirmed by XRD. In the thermodynamic study, the maximum peak temperatures for DSC curves at various heating rates were used to determine the activation energy $\left(E_{a}\right)$ of the hydroxysodalite formation. With magnesium oxide and cobalt oxide, the formation process was found to be exothermic while it was endothermic with iron oxide.
\end{abstract}

Keywords: hydroxysodalite, DSC, alkali-activation, kaolinite, metal oxide

\section{INTRODUCTION}

Hydroxysodalite (HS) is a hydrated crystalline aluminosilicate zeolite with the formula $\left(\mathrm{Na}_{8}\left[\mathrm{AlSiO}_{4}\right]_{6}\right.$ $\left.(\mathrm{OH})_{2} \cdot \mathrm{nH}_{2} \mathrm{O}\right)$. Due to its distinct physicochemical properties, hydroxysodalite has many important industrial and environmental applications, such as adsorption, catalysis and removal of impurities [1, 2]. It is well known that there is an increasing demand for synthetic hydroxysodalite due to the shortage of available natural sources. Therefore, various methods for the synthesis of hydroxysodalite have been developed. Recently, Golbad et al. have employed a hydrothermal activation process to synthesize hydroxysodalite [3]. Synthetic hydroxysodalites offer many advantages over natural hydroxysodalites, such as low cost and high purity [4].

\footnotetext{
* Corresponding author. Email: ehab@ju.edu.jo, ehabju@gmail.com
}

Khajavi et al. reported that HS crystals can be successfully synthesized at different synthesis temperatures $\left(90-140^{\circ} \mathrm{C}\right)$ for different synthesis times (3.5-24 h) via direct hydrothermal synthesis [5]. Additionally, the authors also reported the synthesis and characterization of supported HS zeolite membranes [6]. Novembre et al. reported on an economic hydrothermal synthesis of $\mathrm{Na}$ zeolites and hydroxysodalite. The authors used kaolinite calcined at $650^{\circ} \mathrm{C}$ as the starting material [ [ Nabavi et al. have studied the effect of crystallization time on the final crystalline products of HS in a hydrothermal synthesis method [8]. The authors investigated the influence of gel molar ratio of $\mathrm{H}_{2} \mathrm{O} / \mathrm{Al}_{2} \mathrm{O}_{3}$ on the particulate properties, such as crystal size and shape. Synthetic hydroxysodalite was applied as highly water selective membranes in the dehydration of various organic alcohols over a wide range of temperatures, pressures and 
compositions. In addition, the membrane's thermal and mechanical stability as well as its performance were evaluated in a series of durability tests.

Andrades et al. have studied the synthesis of hydroxysodalite from kaolin waste using different $\mathrm{NaOH}$ concentrations in the reaction medium. It was concluded that the amount of produced sodalite is directly proportional to the concentration of $\mathrm{NaOH}$ used in the hydrothermal synthesis [9]. Temuujin et al. have prepared hydroxysodalites by the hydrothermal treatment alkaline solution of kaolinite calcined at the low temperature of $150^{\circ} \mathrm{C}$ [10].

Recently, Marsh et al. have demonstrated the possibility of easy, cheap and efficient production of hydroxysodalite from kaolinite by activation with sodium hydroxide solution with no prior activation of the precursor and no hydrothermal conditions [11]. Other methods of preparation were employed, such as sonochemical synthesis [12].

DSC analysis is used to measure melting temperature, heat of fusion, latent heat of melting, reaction energy and temperature, glass transition temperature, crystalline phase transition temperature and energy, precipitation energy and temperature, denaturization temperatures, oxidation induction times, and specific heat or heat capacity. Moreover, DSC analysis measures the amount of energy absorbed or released by a sample when it is heated or cooled, providing quantitative and qualitative data on endothermic (heat absorption) and exothermic (heat evolution) processes [13-16].

Kissinger [17] proposed that the method of differential thermal analysis can be used to obtain information about the kinetics and the reaction order of simple decomposition reactions. He demonstrated that the dominant factor controlling the shape and position of the differential thermal analysis peak is the nature of the reaction itself.

Several researchers have used the mathematical models and assumptions proposed by Kissinger and formulated an equation that relates the activation energy of a process to the heating rate [18-21].

Kissinger assumed that for an Arrhenius dependence of the rate constant on temperature, and the 'reaction order model' of the conversion function. Accordingly, a modified Kissinger equation can be written as in Eq. (1):

$$
\ln \frac{\beta}{T_{m}^{2}}=\ln \frac{A R}{E}+\ln \left[n\left(1-\alpha_{m}\right)^{n-1}\right]-\frac{E}{R T_{m}} .
$$

Here $E$ is the activation energy, $A$ is the pre-exponential factor, $\beta$ is the heating rate, $n$ is the reaction order, $\alpha_{m}$ is the conversion degree, $T_{m}$ is the peak (maximum) temperature, $R$ is the gas constant; index $m$ is used for the maximum of the reaction rate. As $1-\alpha_{m}$ is a constant for a given value of $n$, a value for $E$ may be obtained from the slope of the plot $\ln \left(\beta / T_{m}{ }^{2}\right)$ vs $1 / T_{m}$ for a series of experiments at different heating rates at relatively high activation energies.

In this work, the process of alkali-activation of kaolinite is used to form metal oxide-based hydroxysodalite. Selected metal oxides $(\mathrm{CoO}, \mathrm{MgO}$, $\mathrm{FeO}$ and $\mathrm{SiO}_{2}$ ) were used to form the metal oxidebased hydroxysodalite. The transformation from kaolinite into hydroxysodalite is studied by DSC and XRD. Various heating rates were chosen to perform the DSC measurements, namely 5, 10, 15, 20 and $25^{\circ} \mathrm{C} / \mathrm{min} . T_{m}$ was measured from DSC curves and the activation energies are then evaluated using the modified Kissenger equation.

\section{EXPERIMENTAL}

\section{Materials}

In this work, all chemicals were used as received: kaolinite $\left(\mathrm{Al}_{2} \mathrm{O}_{7} \mathrm{Si}_{2} \cdot \mathrm{H}_{2} \mathrm{O}, 258.2 \mathrm{~g} / \mathrm{mol}\right.$, Sigma-Aldrich), sodium hydroxide ( $\mathrm{NaOH}, 40.0 \mathrm{~g} / \mathrm{mol}$, SigmaAldrich), magnesium oxide ( $\mathrm{MgO}, 40.3 \mathrm{~g} / \mathrm{mol}$, INC), cobalt (II) oxide (CoO, $74.9 \mathrm{~g} / \mathrm{mol}$, INC), silicon dioxide $\left(\mathrm{SiO}_{2}, 60.1 \mathrm{~g} / \mathrm{mol}\right.$, Sigma-Aldrich) and iron (II) oxide (FeO, $71.8 \mathrm{~g} / \mathrm{mol}, \mathrm{BDH})$. De-ionized water was used in all preparations.

\section{Sample preparation}

Samples were prepared by gently mixing the kaolinite with the metal oxide to obtain a homogenous powder mixture. Alkali activation was attained by the gradual addition of drops of sodium hydroxide solution $(8.3 \mathrm{M})$ and distilled water to the mixture. The mixture was kneaded to form a solid paste. This procedure was applied for oxides of magnesium, cobalt, silicon and iron. The mixture composition in weight percentages was as follow: $50 \%$ kaolinite, $10 \%$ metal oxide, $10 \%$ sodium hydroxide and $30 \%$ distilled water.

\section{Characterization}

The freshly made samples were tested for powder $\mathrm{X}$-ray diffraction (XRD) and differential scanning 
calorimetry (DSC). Powder XRD was used to determine the phase composition changes upon the alkali activation. The XRD patterns were recorded with a Philips PW-1710 automated diffractometer with a $\mathrm{Cu}$ tube operated at $40 \mathrm{kV}$ and $30 \mathrm{~mA}$. Divergence and receiving slits were set at 1 and 0.1 units, respectively. XRD data were measured at room temperature in a stationary sample holder.

To study the reactivity, DSC tests were performed with a Netzsch DSC 204 F1 differential scanning calorimeter (DSC) (Selb Bavaria, Germany), using reusable high pressure gold-plated stainless steel crucibles at different heating rates of 5, 10, 15, 20 and $25^{\circ} \mathrm{C} / \mathrm{min}$. The test involved heating from the room temperature to $300^{\circ} \mathrm{C}$, cooling to $0^{\circ} \mathrm{C}$, then heating again to $300^{\circ} \mathrm{C}$. XRD and DSC measurements were done for all kaolinite-metal oxide solid pastes as well as the blank kaolinite sample.

\section{RESULTS AND DISCUSSION}

The full transformation from kaolinite into hydroxysodalite by alkali-activation of pure kaolinite using different metal oxides is confirmed by the XRD diffraction illustrated in Fig. 1.

The XRD patterns of the pure kaolinite (Fig. 1(a)) contains ca. 99 wt.\% kaolin and quartz with less than $1 \mathrm{wt} . \%$ of other components. Kaolinite has two characteristic XRD peaks around 12.3 and $24.6^{\circ} 2 \theta$. All of XRD patterns of hydroxysodalite produced by alkali activation in the presence of metal oxides

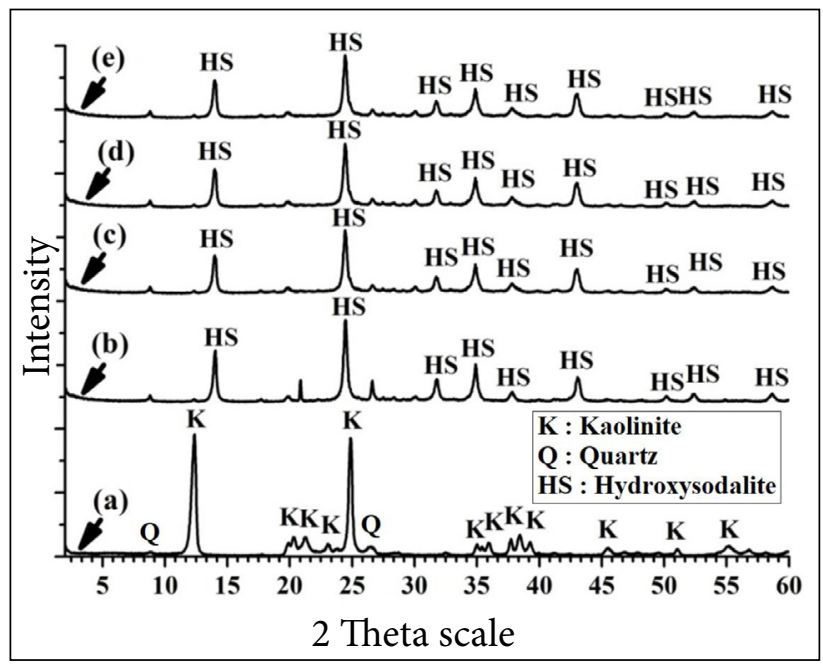

Fig. 1. XRD patterns of (a) pure kaolinite, (b) alkali-activated kaolinite and $\mathrm{SiO}_{2^{\prime}}(\mathrm{c})$ alkali-activated kaolinite and $\mathrm{COO}$, (d) alkali-activated kaolinite and $\mathrm{Fe} O$ and (e) alkali-activated kaolinite and $\mathrm{Mg}$ are very similar and exhibit a significant change to the pure kaolinite XRD pattern. The two major XRD peaks around 12.3 and $24.6^{\circ} 2 \theta$ of kaolinite have disappeared and some new hydroxysodalite peaks appeared. Similar results have been previously reported for the conversion of kaolinite to sodalite [22].

DSC curves for the hydroxysodalite produced by the alkali activation of a mixture of kaolinite and $\mathrm{SiO}_{2}$ at various heating rates $\left(5,10,15,20\right.$ and $25^{\circ} \mathrm{C} /$ $\mathrm{min}$ ) are shown in Fig. 2. Since silicon is the main

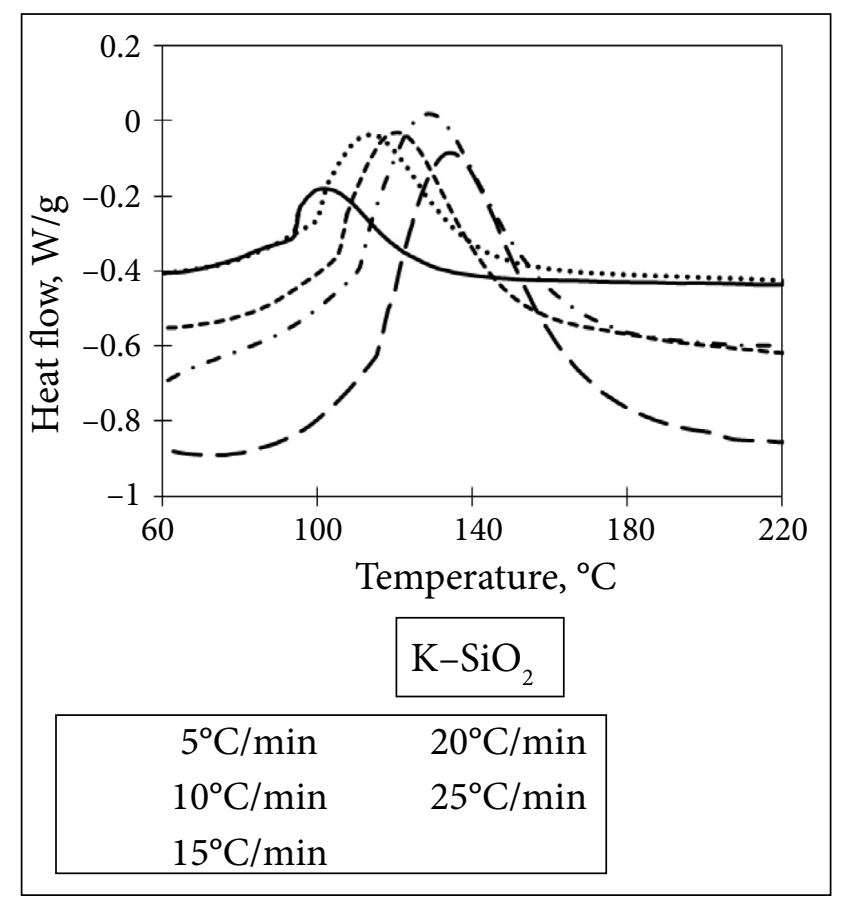

Fig. 2. DSC curves of the alkali-activation of pure kaolinite and silicon oxide at heating rates $5,10,15,20$ and $25^{\circ} \mathrm{C} / \mathrm{min}$

component of hydroxysodalites, silicon dioxide was used as an inert oxide compared to the hydroxysodalites produced with other metal oxides $(\mathrm{CoO}, \mathrm{MgO}$ and $\mathrm{FeO}$ ). Figures $3-5$ illustrate the DSC curves for the hydroxysodalites produced by mixing with $\mathrm{CoO}$, $\mathrm{MgO}$ and $\mathrm{FeO}$, respectively. The results for the DSC experiments for the formation of hydroxysodalite using different metal oxides at $5^{\circ} \mathrm{C} / \mathrm{min}$ are presented in Table 1 .

When compared to the addition of silicon dioxide, the results show that $\mathrm{MgO}$ and $\mathrm{CoO}$ provided extra heat for the formation process amounting to 83.8 joules per mole for $\mathrm{MgO}$ and 156.5 joules per mole for $\mathrm{CoO}$. For the $\mathrm{FeO}$, the heat of reaction noticeably decreased in comparison with the silicon 


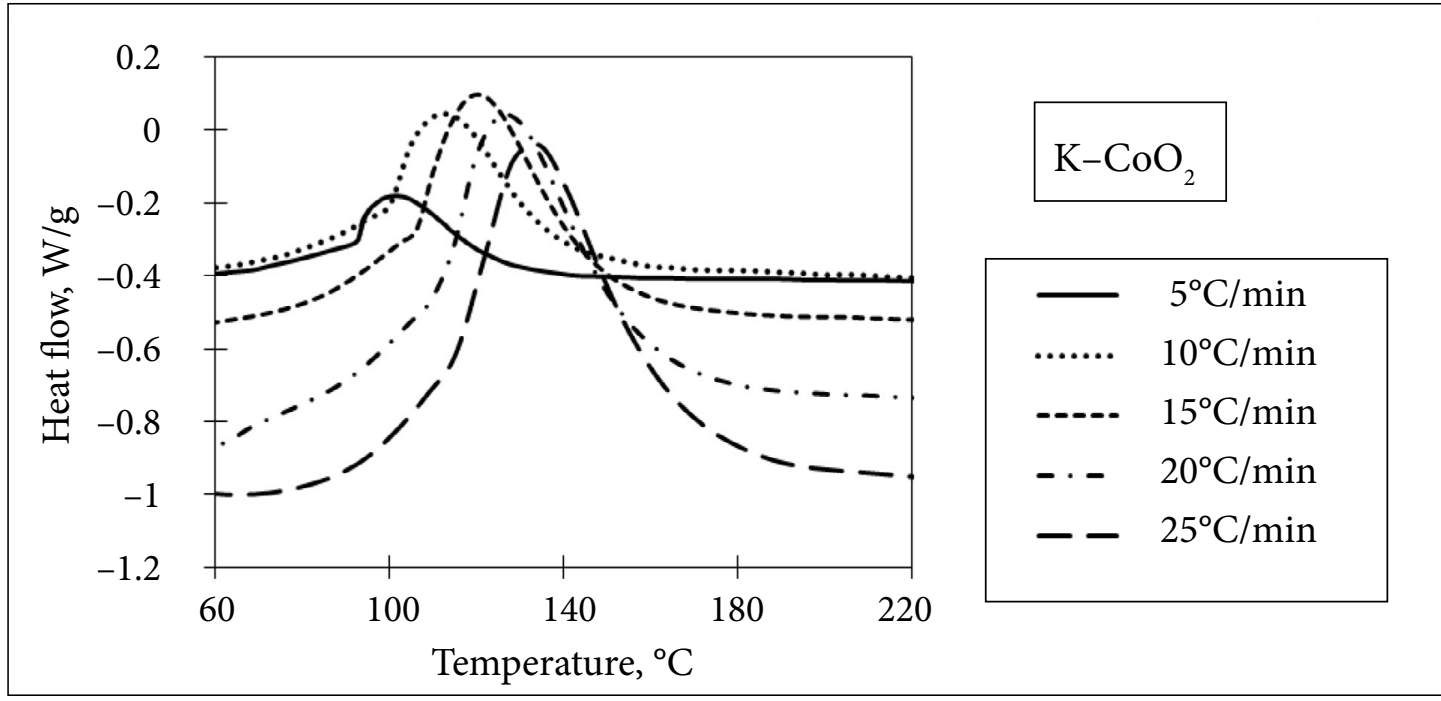

Fig. 3. DSC curves of the alkali-activation of pure kaolinite and cobalt oxide at heating rates $5,10,15,20$ and $25^{\circ} \mathrm{C} / \mathrm{min}$

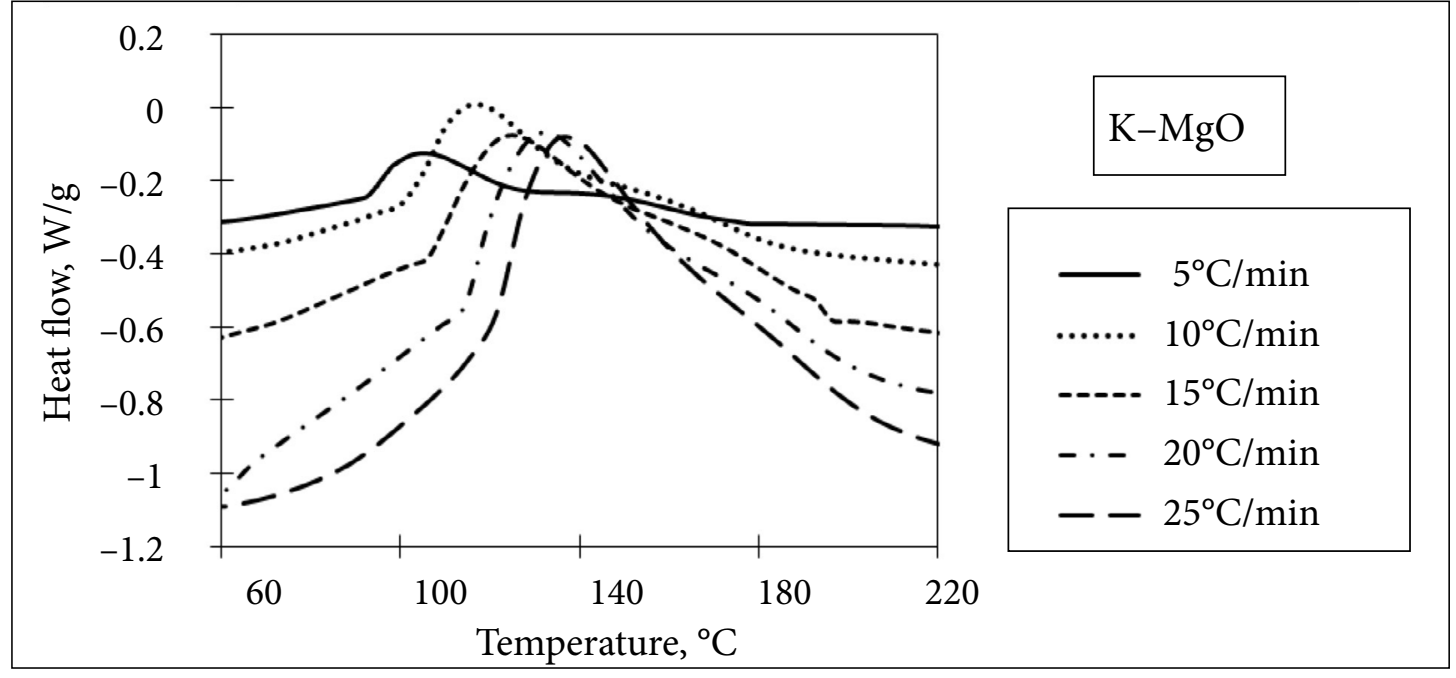

Fig. 4. DSC curves of the alkali-activation of pure kaolinite and magnesium oxide at heating rates $5,10,15,20$ and $25^{\circ} \mathrm{C} / \mathrm{min}$

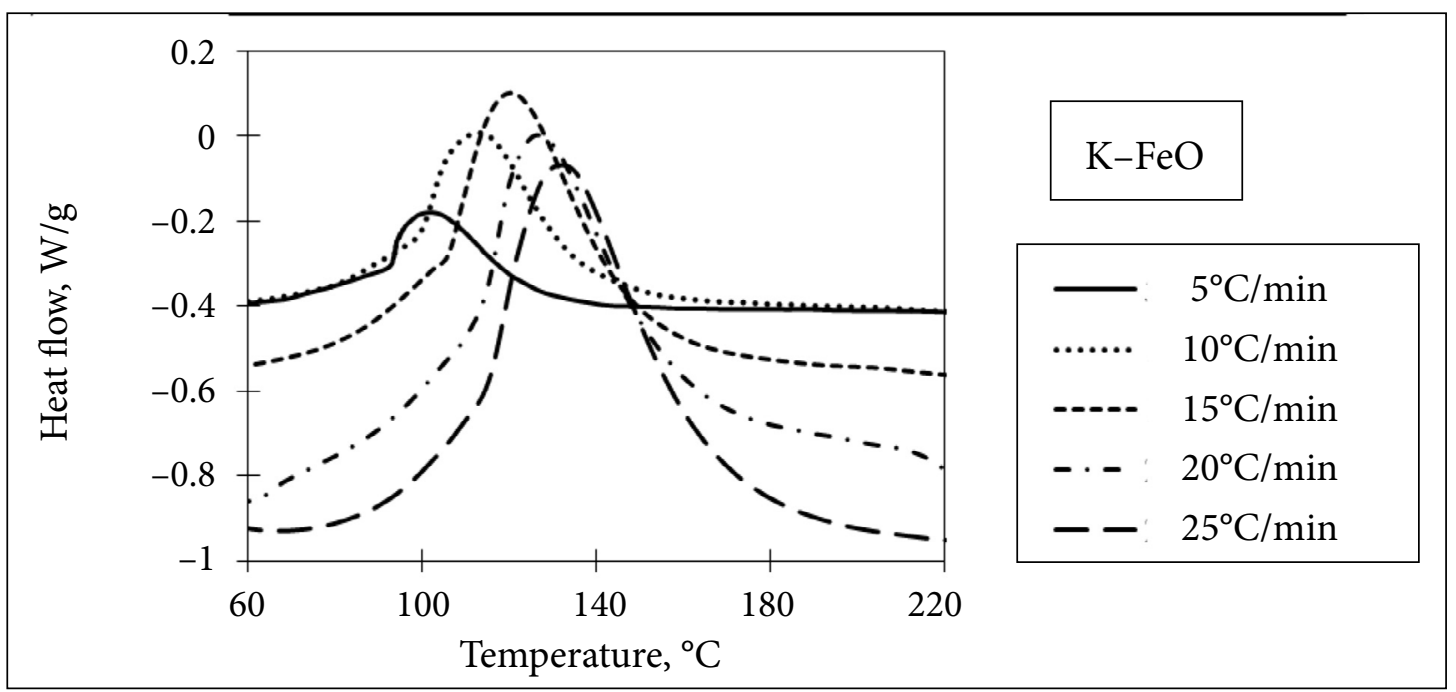

Fig. 5. DSC curves of the alkali-activation of pure kaolinite and iron oxide at heating rates $5,10,15,20$ and $25^{\circ} \mathrm{C} / \mathrm{min}$ 
Table 1. DSC data obtained at heating rates of 5, 10, 15, 20 and $25^{\circ} \mathrm{C} / \mathrm{min}$ of the alkali-activated kaolinite and silicon dioxide, cobalt oxide, iron oxide and magnesium oxide

\begin{tabular}{|c|c|c|c|c|c|}
\hline Metal oxide & Heating rate, ${ }^{\circ} \mathrm{C} / \mathrm{min}$ & $\Delta H, J / g$ & $T_{m},{ }^{\circ} \mathrm{C}$ & $10^{3} / T_{m} K^{-1}$ & $\ln \left(ß / T_{m}{ }^{2}\right)$ \\
\hline \multirow{5}{*}{$\mathrm{K}-\mathrm{SiO}_{2}$} & 5 & 121 & 101 & 2.67 & -10.24 \\
\hline & 10 & 90 & 114 & 2.58 & -9.61 \\
\hline & 15 & 84 & 121 & 2.54 & -9.24 \\
\hline & 20 & 83 & 129 & 2.49 & -9.00 \\
\hline & 25 & 82 & 134 & 2.45 & -8.80 \\
\hline \multirow{5}{*}{$\mathrm{K}-\mathrm{CoO}$} & 5 & 142 & 101 & 2.67 & -10.24 \\
\hline & 10 & 109 & 112 & 2.59 & -9.61 \\
\hline & 15 & 107 & 119 & 2.55 & -9.24 \\
\hline & 20 & 99 & 128 & 2.50 & -8.99 \\
\hline & 25 & 83 & 131 & 2.47 & -8.79 \\
\hline \multirow{5}{*}{$\mathrm{K}-\mathrm{FeO}$} & 5 & 116 & 101 & 2.67 & -10.20 \\
\hline & 10 & 117 & 115 & 2.58 & -9.62 \\
\hline & 15 & 114 & 121 & 2.54 & -9.25 \\
\hline & 20 & 109 & 125 & 2.51 & -8.98 \\
\hline & 25 & 102 & 135 & 2.45 & -8.80 \\
\hline \multirow{5}{*}{$\mathrm{K}-\mathrm{MgO}$} & 5 & 142 & 106 & 2.64 & -10.26 \\
\hline & 10 & 114 & 115 & 2.58 & -9.62 \\
\hline & 15 & 112 & 119 & 2.55 & -9.24 \\
\hline & 20 & 101 & 132 & 2.47 & -9.01 \\
\hline & 25 & 89 & 138 & 2.43 & -8.82 \\
\hline
\end{tabular}

dioxide. This behaviour can be explained by the possible side reaction between $\mathrm{FeO}$ and $\mathrm{NaOH}$ to form a goethite phase (iron (III) oxide-hydroxide). The lowest value of Tonset (see graphs) was obtained using $\mathrm{CoO}$ indicating a relatively faster reaction. The energy profile of the exothermic reaction of the hydroxysodalite formation is summarized in Fig. 6.

According to the Kissenger equation, the activation energy of the hydroxysodalite crystallization can be calculated based on the DSC measurements at different heating rates. For the kaolinite-silicon dioxide system, DSC data were obtained at heating rates of $5,10,15,20$ and $25^{\circ} \mathrm{C} / \mathrm{min}$ of the alkali-activated kaolinite and silicon dioxide. The curves are illustrated in Figs. 2- 5 . The calculations based on these curves are tabulated in Table 2. The resulting Kissinger plot obtained by plotting the quantity of $\ln \left(\boldsymbol{\beta} / T_{m}{ }^{2}\right)$ against $1 / T_{m}$ is presented in Fig. 7. In the Kissinger plot, the activation energy is calculated from the slope of the linear equation. The results showed that the energy needed for the dissolution (see Fig. 6)

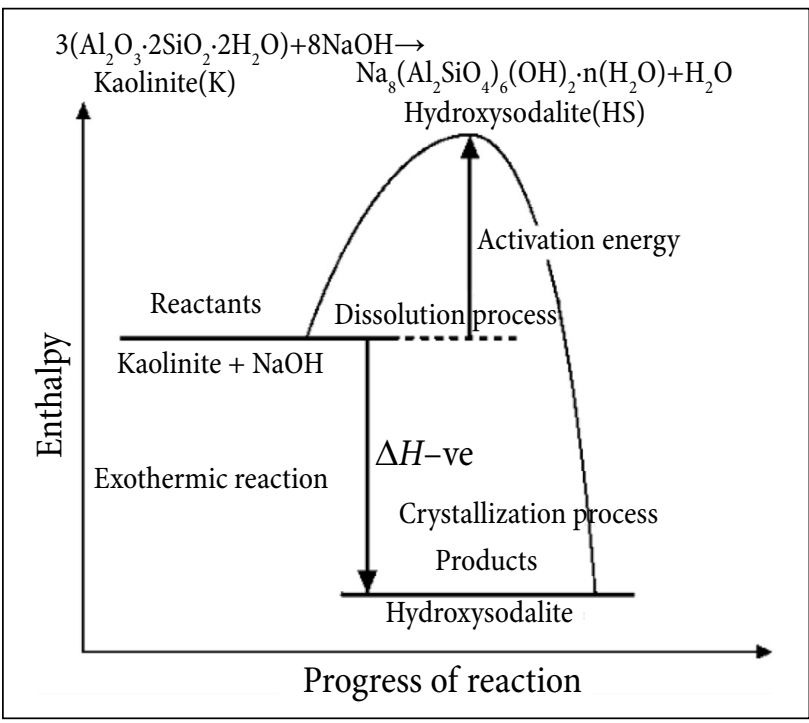

Fig. 6. Energy profile of the exothermic reaction of the hydroxysodalite formation

of $\mathrm{Si}(\mathrm{OH})_{4} \mathrm{O}^{-}\left(\mathrm{Si}^{4+}\right)$ and $\mathrm{Al}(\mathrm{OH})_{4}^{-}\left(\mathrm{Al}^{3+}\right)$ from kaolinite is equivalent to $54.7 \mathrm{~kJ} / \mathrm{mol}$.

The same procedure was applied to DSC data for the different metal oxide-kaolinite systems. 


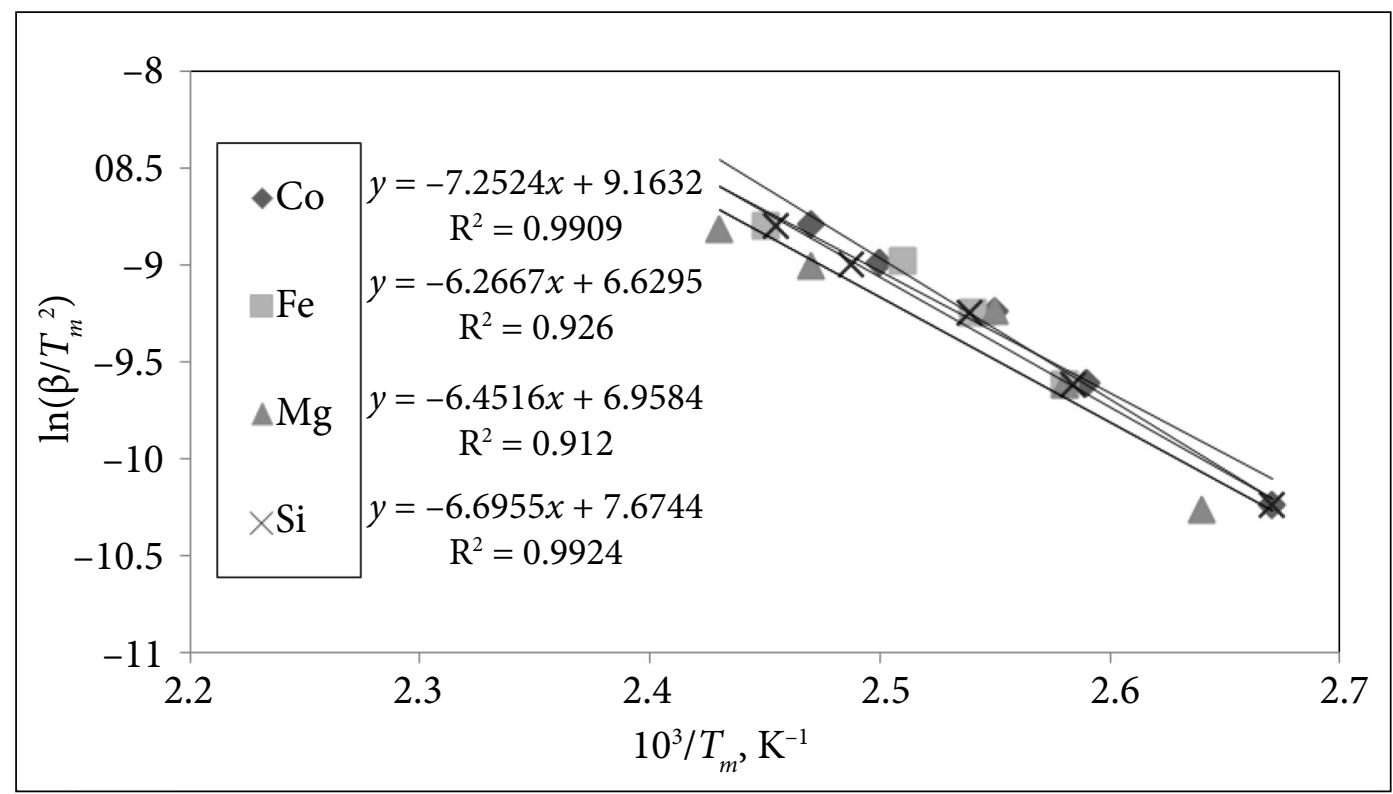

Fig. 7. Kissinger plot of the hydroxysodalite formation from the alkali-activation of kaolinite and each of cobalt, iron, magnesium and silicon oxides

Figures 3 -5 illustrate the DSC curves of the alkali-activation of pure kaolinite and $\mathrm{CoO}, \mathrm{FeO}$ and $\mathrm{MgO}$ at heating rates of $10,15,20$ and $25^{\circ} \mathrm{C} /$ min. The resulting necessary data for producing the Kissinger plot are tabulated for the three oxides $(\mathrm{CoO}, \mathrm{FeO}$ and $\mathrm{MgO})$ in Figs. $3-5$. Since Fig. 7 is the Kissinger plot of the hydroxysodalite formation from the alkali-activation of kaolinite and each of the studied oxides with the results summarized in Fig. 6, it is clear that both $\mathrm{FeO}$ and $\mathrm{MgO}$ showed a decrease in the activation energy when compared to that of $\mathrm{SiO}_{2}$. Whereas, an increase in activation energy is noticed in the case of $\mathrm{CoO}$.

Table 2. Activation energy obtained from the Kissinger slope

\begin{tabular}{c|c|c}
\hline Metal oxides & $\begin{array}{c}\text { Kissinger } \\
\text { slope }=-\boldsymbol{E}_{\boldsymbol{a}} / \boldsymbol{R}\end{array}$ & $\begin{array}{c}\text { Activation energy } \\
\boldsymbol{E}_{\boldsymbol{a}}, \mathbf{k J} / \mathbf{m o l}\end{array}$ \\
\hline Cobalt & -7.2524 & 60.30 \\
\hline Iron & -6.2667 & 52.10 \\
\hline Magnesium & -6.4516 & 53.64 \\
\hline Silicon & -6.6955 & 55.67
\end{tabular}

\section{CONCLUSIONS}

Metal oxide-based hydroxysodalite was prepared by the alkali-activation of kaolinite. The thermodynamic method of DSC employing the Kissenger equation is used to evaluate the activation energy for the formation of hydroxysodalite. Several metal oxide-based hydroxysodalites including $\mathrm{CoO}, \mathrm{FeO}$ and $\mathrm{MgO}$ were used in the preparation. XRD diffraction patterns are consistent with the pure kaolinite and the produced hydroxysodalite. The formation process was exothermic with $\mathrm{MgO}$ and $\mathrm{CoO}$, while it was endothermic with $\mathrm{FeO}$. The activation energy was the highest in the case of $\mathrm{CoO}$. Whereas $\mathrm{MgO}$ and $\mathrm{FeO}$ showed activation energies lower than that of $\mathrm{SiO}_{2}$.

\section{ACKNOWLEDGEMENTS}

This research was funded by the Research Grant from the Deanship of Scientific Research at the University of Jordan (Project Nos. 2007 and 2176).

Received 5 March 2020 Accepted 30 March 2020

\section{References}

1. S. Auerbach, K. Carrado, P. Dutta, Handbook of Zeolite Science and Technology, 1st edn., CRC Press (2003).

2. M. Gougazeh, F. Kooli, J. Buhl, Clays Clay Miner., 67, 143 (2019).

3. S. Golbad, P. Khoshnoud, N. Abu-Zahra, Int. J. Environ. Sci. Technol., 14, 135 (2016).

4. X. Xu, Y. Bao, C. Song, W. Yang, J. Liu, L. Lin, Microporous Mesoporous Mater., 75, 173 (2004). 
5. S. Khajavi, S. Sartipi, J. Gascon, J. Jansen, F. Kapteijn, Microporous Mesoporous Mater., 132, 510 (2010).

6. S. Khajavi, F. Kapteijn, J. Jansen, J. Membr. Sci., 299, 63 (2007).

7. D. Novembre, B. Di Sabatino, D. Gimeno, C. Pace, Clay Miner., 46, 339 (2011).

8. N. Nabavi, T. Mohammadin, M. Kazemimoghadam, Ceram. Int., 40, 5889 (2014).

9. R. Andrades, R. Neves, F. Diaz, A. Júnior, J. Nano Res., 61, 51 (2020).

10. J. Temuujin, K. Okadaa, K. MacKenzie, Mater. Lett., 52, 91 (2002).

11. A. Marsh, A. Heath, P. Patureaub, M. Evernden, P. Walker, Microporous Mesoporous Mater., 264, 125 (2018).

12. W. Kim, D. Choi, S. Kim, Mater. Trans., 51, 1694 (2010).

13. S. Khajavi, J. Jansen, F. Kapteijn, J. Membr. Sci., 326, 153 (2009).

14. C. Schick, D. Lexa, L. Leibowitz, in: E. Kaufmann (ed.), Characterization of Materials, John Wiley \& Sons, Inc., Hoboken (2012).

15. J. Harveya, N. Saadatkhaha, G. Dumont-Vandewinkela, S. Ackermannb, G. Patiencea, Can. J. Chem. Eng., 96, 2518 (2018).

16. Anderson Materials [www.andersonmaterials.com/ dsc.html].

17. H. Kissinger, Anal. Chem., 29, 1702 (1957).
18. P. Budrugeac, E. Segal, J. Therm. Anal. Calorim., 88, 703 (2007)

19. Y. Cheng, Anal. Methods, 2, 1255 (2007).

20. J. Cai, W. Wu, R. Liu, Indus. Eng. Chem. Res., 51, 16157 (2012).

21. J. Park, S. Oh, H. Lee, H. Kim, K. Yoo, Korean Z. Chem. Eng., 17, 489 (2000).

22. H. Zhao, Y. Deng, J. Harsh, M. Flury, J. Boyle, Clays Clay Miner., 52, 1 (2004).

Ehab AlShamaileh, Muayad Esaifan,

\section{Qusay Abu-Afifeh}

\section{HIDROKSISODALITO METALO OKSIDO FORMAVIMAS KAOLINITO ŠARMINĖS AKTYVACIJOS BŪDU}

Santrauka

Hidroksisodalito metalo oksido susidarymas kaolinito šarminès aktyvacijos būdu buvo tiriamas rentgeno spindulių difrakcija ir diferencine skenuojančia kalorimetrija. Hidroksisodalitas buvo formuojamas naudojant skirtingus metalų oksidus - $\mathrm{CoO}, \mathrm{MgO}$, $\mathrm{FeO}$ ir $\mathrm{SiO}_{2}$. Iš gautų rezultatų apskaičiuota hidroksisodalito susidarymo aktyvacijos energija. Nustatyta, kad panaudojus magnio ir kobalto oksidus susidarymo procesas yra egzoterminis, o geležies oksidą - endoterminis. 